\title{
Linguistic Ambiguity in the Holy Qur'ān and Its English Translations
}

\author{
Ebrahim Davoudi Sharifabad (Corresponding author) \\ School of Languages, Literacies, and Translation, University Sains Malaysia \\ K18C-008, Jalan Aman, 11800 Universiti Sains Malaysia, Penang, Malaysia \\ Tel: 60-124-426-104Ｅ-mail: davoudiebrahim@gmail.com
}

\author{
Tengku Sepora Tengku Mahadi \\ School of Languages, Literacies, and Translation, University Sains Malaysia \\ 11800 Universiti Sains Malaysia, Penang, Malaysia \\ Tel: 60-4653-4881Ｅ-mail: tsepora@usm.my
}

\author{
Mohammad Sadegh Kenevisi \\ School of Humanities, University Sains Malaysia, \\ 01, 07, 1A, Block A, Sunny Ville, Jalan Batu Uban \\ 11700 Gelugor, Pulau Penang, Malaysia
}

Tel: 60-124-537-904 E-mail: kenevisi.sadegh@gmail.com

Received: April 29, 2012 Accepted: May 31, 2012 Published: September 1, 2012

doi:10.5296/ijl.v4i3.1730ＵRL: http://dx.doi.org/10.5296/ijl.v4i3.1730

\begin{abstract}
The present paper aims at classifying different types of ambiguities in the Holy Qur'ān and then evaluating and criticizing the made English translations of the ambiguous verses. To do so, a classification of linguistic ambiguity is offered and the samples of these classifications from the Holy Qur'ān are mentioned. The ambiguous verses are classified as phonological, lexico-semantic and conjugational structural ambiguities. The qualities of translations and English translation strategies of the stated verses are also investigated. There are many linguistic ambiguous verses in the Holy Qur'ān that may cause a trouble for a translator.

Keywords: Ambiguity, Phonological ambiguity, Lexico-Semantic ambiguity, Conjugational structural ambiguity, The holy qur'ān, translation procedures
\end{abstract}




\section{Introduction}

Translating a text into another language may not be an easy task. Due to the differences and complexities of languages, a comprehensive knowledge of the two languages is difficult to be obtained on the part of the translator. One of the linguistic complexities that makes the translation a tough task is linguistic ambiguity. Ambiguity is an issue that makes problems for the translator. It can both be in the source text itself or it may occur in the translated text. Sometimes, a text is ambiguous. So, the translator cannot get the meaning across and consequently translates that text ambiguously. At times, source texts may not be ambiguous, but since the translator has got the point mistakenly, s/he produces an ambiguous translation.

To produce unambiguous translations, the translators should consider the type of the text they are translating. Because of the existence of different types of texts, there may be different types of translations, each one enjoying its own characteristics; for instance, for literary or religious texts there are literary or religious translations. A literary or religious translator must be fully aware, of literary or religious genres and texts. So, each text should be translated according to its own specifications.

Translating religious texts is very delicate and important, since such kinds of texts have to do with people's ideologies and beliefs. That is why the translator of such texts should try her/his best to produce as more appropriate translation as possible. As a religious text, the Holy Qur'ān enjoys a complicated text. Since the verses of the Holy Qur'ān are revealed in different situations, apart from translator's linguistic knowledge, s/he should be familiar with the context of situation in which a verse is revealed. As one of the important issues, ambiguity is frequently observed in the Holy Qur'ān. Hence, many of the produced translations of the ambiguous verses suffer some shortcomings. The reasons of such shortcomings are both linguistic differences and complexities of this Holy Book and sometimes the translator's lack of knowledge of context of situation.

\section{Statement of the Problem}

Due to the significance of religious texts, the proper transference and translation of the Holy Qur'ān is very important. If the translations of the Holy Qur'ān are problematic, people would not be able to understand the meanings of this Holy Book, and the very aim of its revelation might not be achieved. Because of the linguistic and contextual differences and complexities of the Qur'ānic text, the translations of the Holy Qur'ān, in one way or in another, suffer from different types of deficiencies. Since it is very difficult to overcome all the translation problems, so at least the translators should do their best to rectify some mistakes. As evident, the Holy Qur'ān is revealed in the Arabic language, and there are many people all over the world who are not familiar with this language, so the proper translation of the Holy Qur'ān is obligatory. One of the most confusing Qur'ānic issues is the existence of ambiguous words or sentences. For the reader of this divine book to understand the meanings of the Holy Qur'ān and especially the meanings of ambiguous verses, the translator of the Holy Qur'ān has to determine the ambiguity and then disambiguate these meanings. 


\subsection{The Qur'ān Translation}

As most of Islamic and Qur'ānic scholars believe, the Qur'ān is a unique text. The uniqueness of the Holy Qur'ān in Yazdani's words "is both in its style and content" (p. 84). Allah, in the Qur'ān expresses the uniqueness of the Holy Qur'ān in His own words:

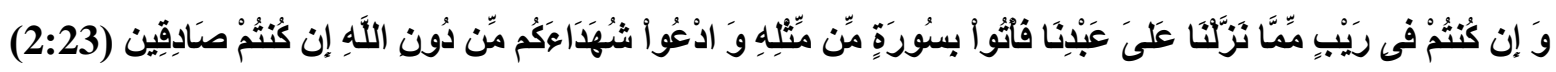

If you be in doubt about what we have sent down unto Our servant ... produce ye then a sūrah (chapter) like unto it ... (2:23) (Mir Ahmed Ali p.39).

According to Mustapha, the linguistic and stylistic process of the Qur'ānic texture is a kind of masterpiece in Arabic language, and the grammatical structure of the Qur'ān in many different ways is different from that of non-Qur'ānic Arabic.

Allah in His Holy Book says:

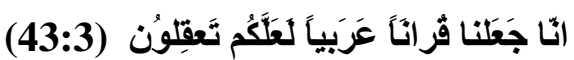

... We have sent it up [sic] as an Arabic Reading so that you may (all) use your reason (43:3)

( Irving, p. 489).

Therefore, the prominence of the Qur'ān structure is so high that Arabs categorize the structure of their language as Qur'ānic Arabic and non-Qur'ānic Arabic (Mustapha [5]). Translating the Holy Qur'ān is, of course, one of the forms of non-Muslim Qur'ānic studies that the medieval and early modern Europe generated. "Access to the Holy Qur'ān via such translations provoked responses from Jewish and Christian authors. Reference to the Qur'ān and the citation of specific passages can be found in many works of Jewish and Christian scholarship from these periods" (Mc Auliffe, p.vii).

Mollanazar and Mohaqeq (p.59) believed that "one of the important factors which influence translation of the Holy Qur'ān is the ideological presuppositions of the Qur'ān translators". In an article on ideological factors and presuppositions which influence the translation of the Holy Qur'ān, the authors have studied three translations of the Qur'ān whose translators have come from different backgrounds and different ideologies. According to them, different ideological presuppositions affect directly or indirectly translations and exegesis (Tafsirs) on these translations. The authors believed that because of the different ideologies there are different translations in terms of "the way they choose equivalence at word level, procedures of translation, and (not) providing footnotes, annotations and explanations" (p. 60). As the above-mentioned study illustrated, cognitive and ideological factors may highly affect the quality of translation of religious texts.

Another important aspect which should be taken into consideration in translating religious texts, especially the Holy Qur'ān, is the issue of inference. As Mosaffa, Ketabi, \& Maimaneh believed, the type of selected words, lexicon juxtaposition and syntactic structure are all the factors that may lead to different inferences which may be in contrast with the religious teachings. Hence, "these inferences at different levels while translating religious texts should be taken into account. As an example, consider translating conditional sentences of type two: 
'If Jesus were alive ....' In English this sentence implicitly means that Jesus is not alive while Christians believe that Jesus Christ is alive" (p. 51).

\subsection{Linguistic Ambiguity}

Since the core of the translation process is linguistics, the study of the languages, source text language and target text language is the main duty of translating. Hence, translation is regarded as a contrastive linguistics study and practice. Robinson believes that contrastive linguistics is a considerable aspect of language that is consistent in the linguistic context. He points out that "since contrastive linguistics has for almost a century been the dominant and indeed almost the only form of language study accepted as linguistics, I do not consider the methodological elaboration of contrastive linguistics to be a particularly a pressing task" (p. $5)$.

Therefore, since the linguistic elements that cause a text translation to be difficult, should be identified and studied contrastively. Ambiguity is one of the difficulties of the linguistic aspect of the translation task namely in rendering the divine verses. It is on the translator to be careful in finding these linguistic ambiguities and then explicating and disambiguating the linguistic ambiguities.

According to Hudson, "ambiguity exists when a form has two or more meanings" (p. 313). According to Hudson, to clarify the ambiguous meaning, "pragmatics, ordinarily, would make clear which meaning is appropriate" (p. 313). Hudson classified ambiguity as "lexical ambiguity and structural ambiguity" (p. 313). According to Hudson, Lexical ambiguity includes: homophones, homographs and homonymy vs. polysemy, and structural ambiguity include grouping ambiguity and function ambiguity (pp.313-314).

Falk compares ambiguity to paraphrase and mentions that "in paraphrase, two or more surface structures that convey the same meaning must have the same deep structure. In ambiguity, a single surface form with several meanings must have several deep structures. Falk makes an example of ambiguity: (1) John is too far away to see. (2) John is too far away for anyone to see him. (3) John is too far away to see anything (p. 202). To analyze the above-mentioned example, Falk considers the first sentence as ambiguous expressed by the second and third sentences. Falk deems that the second and third sentences are also the paraphrases of the first one and these paraphrases have the same deep structure, so the deep structures of the first and second sentences are the same, both the underlying deep structures of the first and the third sentences are dissimilar.

According to Larson, ambiguity can be the result of a problem in understanding the context or linguistic contextual sense and meaning. By an example, he clarifies the point. "This suit is lighter" (p. 107). As Larson argues, this phrase is ambiguous. It can mean that "the suit does not weight as much as another or that the color of the suit is not as dark as another". (P. 107). As we see here, the ambiguity arises due to the existence of the two senses and lack of context. So, it can be concluded from what Larson mentions that apart from understanding the contextual meanings and senses, the translator should also know the 'the components of the primary sense'. "No equivalent lexical items will have the same senses from language to 
language. Even primary meanings that look the same at first may have additional components that can distort the meaning if used without care" (108). As understood from the above statement, the translator should have sufficient contextual clues to find the desired meaning. Larson notes that "ambiguities often arise when the translator only knows one or two senses of a word and does not know the context needed to signal the correct meaning" (p. 108). So, it can be said that denotative meaning is also of significance in knowing the ambiguities. Clearly, the denotative meaning is about the additional and secondary meaning of a word.

As a translation studies scholar, Newmark defines and clarifies the ambiguity with relation to translation. He points out that most sentences have got both lexical and grammatical ambiguity. He distinguishes between these kinds of ambiguities as linguistic or referential ambiguities. He classifies such ambiguities as 'referential and linguistic'. He argues that 'micro and macrocontext can hopefully clear up such ambiguities. So, according to Newmark, the contribution of the translator in such cases at the macrocontext level is first to specify whether it is a referential or linguistic ambiguity or it is between the two extremes, then to disambiguate the ambiguous sentence or word. The distinction of referential and linguistic ambiguities and the translator's contribution is mentioned as:

A referential ambiguity must always be retained and pointed out, if it cannot be cleared up by an expert. A linguistic ambiguity may enrich a text as both meanings may be intended, and the translator should attempt to reproduce the ambiguity, but if he is unable to do so, he normally translates one of the meanings and let the other go. Whilst lexical ambiguities are more common, grammatical ambiguities arise when the point of stress in a clause or when relationship between word-group or clauses in a larger unit are not clear, i.e. does not know 'what goes with what (p. 122).

Another classification for ambiguity by Javaheri is that of literary and linguistic ambiguities. He names such ambiguities conscious and unconscious ambiguities as well. In literary ambiguity, the author makes ambiguous writings intentionally and to do so, he may sometimes use figures of speech. Javaheri calls such an ambiguity an artistic-literary ambiguity. Figures of speech such as irony and polysemy are considered as artistic and conscious ambiguity used intentionally by the speaker or writer in the speech or writing. However, linguistic ambiguity is the one which exists in a language and is not mentioned by the author deliberately. It occurs in languages due to the linguistic and cultural differences of the languages. Of course, the literary ambiguity mentioned by Javaheri is not our concern and it is frequently used in literature.

\subsubsection{Linguistic Ambiguity in the Holy Qur'ān}

Three kinds of linguistic ambiguities in the Holy Qur'ān and their English translation explicitation procedures are studied in this research. There are many samples of such ambiguities in the Holy Qur'ān, but in this research, just some samples of them along with their translations are compared and contrasted. The types of linguistic ambiguities to be investigated in the data analysis section are structural, lexico-semantic and phonological ambiguities. 


\subsection{Nida's Formal and Dynamic Theory of Equivalence in Translation}

As a Bible translator advocating Christianity, Eugene Nida made a major contribution to the science of translation and translating religious texts. Nida's theory of equivalence was a reform in the world of translation studies. Nida proposed two basic types of equivalence: 1) formal equivalence and 2) dynamic equivalence. "Formal equivalence focuses attention on the message itself, in both form and content ...." (P. 159). The one that is concerned with the message in the receptor language should match as closely as possible the different elements in the source language (Nida as cited in Munday).

Therefore, it can be concluded that formal equivalence is intensely based on the source language text structure which plays a key role in determining accuracy and correctness in translation. The use of scholarly footnotes to let students gain close access to the language and customs of the source culture is of marked characteristics of formal equivalence (Munday,)

In formal-equivalence based type of translation, the choice of correspondences are as "poetry to poetry, sentence to sentence and concept to concept". Based on this formal orientation, the message in the receptor language should match closely different elements in the SLT. It means that the criterion of determining the accuracy and correctness of translation is comparing the message in the receptor culture with the same in the source culture. Such a formal kind of translation, which "typifies the structural equivalence", is called "gloss translation". "A gloss translation of this type is designed to permit the reader to identify himself as fully as possible with a person in the source-language context, and to understand as much as he can of the customs, manner of thought, and means of expression " (Hatim and Munday, p.167).

In contrast, a translation which is based on dynamic equivalence is the one attempting to produce a dynamic rather a formal equivalence. Such a translation is mainly based on the equivalent effect principle. This kind of translation is not concerned with matching the message in the source language to the message in the target language, but is to produce exactly the same effect on the receptor language reader. Nida stressed that "the relationship the receptor and message should be substantially the same as that which existed between the original receptors and the message. Dynamic equivalence is the closest natural equivalent to the source-language message"(p. 159).

To Nida, a dynamic-equivalence based type of translation is that which does not sound foreign to the reader and is quite natural to him/her. He maintained that the translation is successful while the equivalent response is achieved, and to achieve equivalent response, correspondence in meaning must have priority over correspondence in style (Munday). The most outstanding contribution of Nida to translation was that by introducing formal and dynamic equivalence, he moved toward the reader, i.e. his approach to translation was receptor-based. 


\section{I Macrothink}

\section{Methodology}

The method followed in this study is descriptive and the researcher, after finding and analyzing the instances of ambiguities, examines the English translations of the related verses of the three kinds of ambiguities mentioned above. Through a descriptive method, the researcher attempts to describe and interpret the status of phenomena. Thus, this research is a comparative study of ambiguities in Arabic and its English translations.

\subsection{Materials}

Since the present thesis intends to apply a contrastive analysis to the Qur'ān and its English translations, it seems sensible that there should be enough variety and quantity concerning the materials. As for quantity, four English translations of the Qur'ān were selected each containing their own characteristics. These translations are various and different from each other in style. The following English translations of the Qur'ān were implemented to the study:

- The English translation of the Qur'ān with detailed commentary by Yusuf Ali

- The English translation of the Qur'ān by Shakir

- The English translation of the Qur'ān by Pikthal

- The English translation of the Qur'ān by Mohsin Khan and Al-Hilali

\subsection{Procedure}

In the present study, the verses of the Qur'ān including any of the mentioned ambiguities and their English translations are compared and contrasted. The procedure is that, first, the Arabic verse, which contains ambiguity is mentioned. Then the English translations are presented and analyzed.

To investigate the mechanisms and procedures existing in the English translations of the ambiguities in the Qur'ān their realizations, the researcher utilized a contrastive analysis of two languages. To have a right examination of the mentioned translations, the researcher found and analyzed the ambiguity, then he focused on the methods and procedures of the made translations.

\section{Data Analysis}

The data of this research are the verses of the Qur'ān in Arabic containing ambiguity and three English translations. First three categorizations of ambiguity are mentioned and the translations of such verses are offered before each verse.

\subsection{Conjugational Structural Ambiguity}

According to Abdul-Raof, structural ambiguity is not a common feature of linguistic discourse. He maintains that "structural ambiguity requires careful exegetical exploration in order to decide its accurate meaning in the target text; a Qur'an translation which lacks reference to Qur'an exegesis leads to innovations and inaccuracies" (p. 74). 


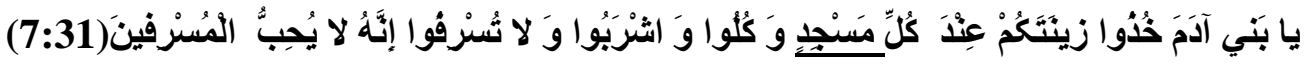

Yusuf Ali: O Children of Adam! Wear your beautiful apparel at every time and place of prayer: eat and drink: But waste not by excess, for Allah loveth not the wasters.

Pickthal: O Children of Adam! Look to your adornment at every place of worship, and eat and drink, but be not prodigal. Lo! He loveth not the prodigals.

Shakir: O children of Adam! Attend to your embellishments at every time of prayer, and eat and drink and be not extravagant; surely $\mathrm{He}$ does not love the extravagant. Mohsin Khan and Al-Hilali: O Children of Adam! Take your adornment (by wearing your clean clothes), while praying and going round (the Tawaf of ) the Kabah, and eat and drink but waste not by extravagance, certainly He (Allah) likes not Al-Musrifoon (those who waste by extravagance).

Some words in Arabic conjugational structures may lead to ambiguity. The Arabic language structure is so unique that a word can be conjugated differently. The word Masjid is ambiguous. It may refer to the time or place of prayer. The three made translations are very different. Yusuf Ali has rendered Masjid to the time and place of prayer. Pickthal translated Masjid as the place of worship, while Shakir's translation of the word Masjid is the time of prayer. The different translation by Mohsin Khan and Al-Hilali is so clear that they have rendered this part based on their own interpretations. Masjid is rendered to the Kabah at the time of Tawaf or circumlocution.

\subsection{Phonological Ambiguity}

The phonological feature investigated here is the stress. If the stress on words changes, the meaning will change as well. In the following example, notice the shift of stress.

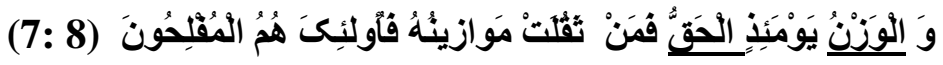

Yusuf Ali: The balance that day will be true (to nicety): those whose scales (of good) will be heavy, will prosper:

Pickthal: The weighing on that day is the true (weighing). As for those whose scale is heavy, they are the successful.

Shakir: And the measuring out on that day will be just; then as for him whose measure (of good deeds) is heavy, those are they who shall be successful; Mohsin Khan and Al-Hilali: And the weighing on that day (Day of Resurrection) will be the true weighing). So as for those whose scale (of good deeds) will be heavy, they will be the successful (by entering Paradise).

According to Javaheri, the stress in this verse is identical with the meaning. If the stress is on the first word, Alwazn, the verse means that "the measuring of the deed is surely done", whereas if the stress is on the second word, Alhaq, this verse means that "the truth is the means of measuring the deeds". Since stress is phonological feature and should be noticed in reading the verse, it is possible that one aspect of ambiguity is considered by the translator and the other ambiguous meaning is left neglected. Regarding the translations of these verses, 
other translators of the Qur'an except Mohsin Khan and Al-Hilali have rendered this verse based on the first meaning of this verse, i.e. the stress is on the word Alwazn. So, all the translators have rendered this verse the same.

\subsection{Lexico-semantic Ambiguity}

The Lexico-semantic ambiguity is the most common kind of ambiguity. There are many ambiguous words in the Holy Qur'an which make the translating of this Holy Book difficult. To translate such lexical and semantic ambiguous elements and due to the polysemy problem, the translators of the Holy Qur'an resort to different dictionaries and interpretations of the Holy Qur'an. Another important factor that should be taken into account by the translators of the Holy Qur'an is knowing the context of the situation of the verses.

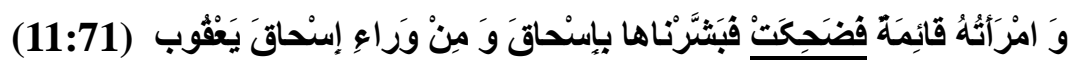

Yusuf Ali: And his wife was standing (there), and she laughed: But we gave her glad tidings of Isaac, and after him, of Jacob.

Pickthal: And his wife, standing by laughed when We gave her good tidings (of the birth) of Isaac, and, after Isaac, of Jacob.

Shakir: And his wife was standing (by), so she laughed, then We gave her the good news of Ishaq and after Ishaq of (a son's son) Yaqoub.

Mohsin Khan and Al-Hilali: And his wife was standing (there), and she laughed (either, because the Messengers did not eat their food or for being glad for the destruction of the people of Lout (Lot). But We gave her glad tidings of Ishaque (Isaac), and after him, of Yaqoob (Jacob).

The word zahekat from the root word of zahaka may mean to laugh or to menstruate. So, the ambiguity arises here. One of the contexts of the situation for this verse is that since Prophet Ibrahim's wife was old and had not been menstruated because of her oldness, and since Allah wanted to give her good tidings of Isaac and after him of Yaquob, she was menstruated, so that she understood that Allah's will to give her Isaac has been fulfilled. Although some other translators of the Qur'an have translated zahekat as to menstruate, all the above-mentioned translators have rendered zahekat as to laugh. As observed, Mohsin Khan and Al-Hilali have rendered this verse based on their own interpretations.

\section{Conclusion}

If the translators of the Holy Qur'ān, before starting to translate the the Holy Qur'ān, study some useful exegeses and interpretations of the Holy Qur'ān, they would undoubtedly make more appropriate and natural translations of this Sacred Book. Studying the exegeses of the Holy Qur'ān causes translators to enjoy a wealthy background of the text type of the Holy Qur'ān and its related problems.

In the investigated English translations of this paper, it was concluded that some of the translators have tried, by making use of addition explicitation translation strategy to explicate the implicated meaning of the ambiguities, while some others failed to notice this point and 


\section{Macrothink}

have made literal translations. One of the important factors in translating the ambiguities is the existence of polysemy. Different kinds of ambiguities investigated in this study require their own translation strategies. The most challenging type of ambiguity investigated in this study is the lexico-semantic one.

The translators' knowledge of the methods and strategies of translation and the ways they are realized in the translation of the Holy Qur'ân is of significance and help to the translators. Translators' knowledge of linguistics is, largely, helpful for them in making a good translation of the Holy Qur'ān. The translators' linguistic knowledge of ST and TT affect the quality of translation greatly. The translators of the Holy Qur'ān should know the language of revelation very well. By studying the exegeses of the Holy Qur'ān, they would be familiar with the language of revelation.

A very important factor in translating ambiguous words and structures is the translator's knowledge of equivalence selection. Sometimes due to the unfamiliarity of the translator about the proper equivalent to be chosen for a word, a phrase and a sentence, the translator makes a mistake and consequently a mistranslation happens. The result of such as wrong equivalent selection is that the translation is then ambiguous itself.

\section{References}

Abdul-Raof, H. (2001). Qur'an Translation: discourse, Texture and Exegesis. London and New York: Routledge.

Al-Hilali. T. D., \& M. Muhsen Khan. (1995) The Nobel Qur'ān. Riyadh: Dar-us-Salam Publications.

Falk, J.A.S. (1978). Linguistics and Language: A Survey of Basic Concepts and Implications. New York:John Wiley and Sons.

Hatim, B., \& Munday, J. (2004). Translation an Advanced Resource Book. London: Routledge.

Hudson, G. (2000). Essential Introductory Linguistics. Massachusetts: Blackwell Publishers Inc.

Irving, T. B. (1998). The Qur'ān, Tehran: Suhravardi.

Javaheri. M. H. (2008). Ambiguity in the Translation of the Qur'an. The Qur'anic Research Quarterly. 53(14). pp. 186-201.

Larson, L. Mildred. (1998). Meaning-based Translation. Boston: University Press of America.

Mc Auliffe, D.J. (e.d). (2001). Encyclopedia of the Qur'ān. Boston: Brill.

Mir Ahmed Ali, S.V. (1998). The Holy Qur'ān. New York: Tahrike Tarsile Qur'ān Inc.

Mollanazar, H., \& Mohaqeq, S.M. (2005). The Holy Qur'ān: Translations and Ideological Presuppositions. Translation Studies Quarterly 3(11), pp.59-67. 
Mosaffa, A, Ketabi, S \& Maimaneh, H.A. (2005). Translation of Religious Texts: Drawbacks, Strategies and Inferences. Translation Studies Quarterly 3(10), pp. 41-54.

Munday, J. (2001). Introducing Translation Studies, Theories and applications. London: Routledge.

Mustapha, H. (1998). Qur'ān Translation, in M.Baker (ed.) (2001) Rutledge Encyclopedia of Translation Studies. London and New York: Routledge, pp.200-4.

Newmark, P. (1998). Approaches to Translation. Singapore: Prentice Hall.

Nida, E. A. (1964). Toward a Science of Translating. Leiden:E.J.Brill.

Pickthall M.M. (2002). The Glorious Qur'an: The Arabic Text with a Translation in English. New York: Tarikhe Tarsil Qur'an Inc.

Robinson, D. (2003). Performative Linguistics Spiking and Translating as Doing Things with Words. New York and London: Rutledge. http://dx.doi.org/10.4324/9780203222850

Shakir. M.H. (1996). The Qur'an: Arabic Text and English Translation.

Yazdani, M. (2004). Transmission of Cohesion through Explicitation in Qur'ānic Translation: a Case Study on Chapter XII: Yusuf. Unpublished master's thesis, Allameh Tabataba'I University, Tehran.

Yusuf Ali. A. (2002). The Qur'an Text Translation and Commentary. New York: Tarikhe Tarsil Qur'an Inc.

\section{Authors}

Ebrahim Davoudi Sharifabad is a PhD candidate of Translation in the School of Languages, Literacies, and Translation, Universiti Sains Malaysia. He has been a researcher and instructor of translation studies for some years in Iran. His field of specialization in translation studies is Translation Theories, Discourse Analysis and mainly translation and linguistics, namely linguistic issues of the Holy Qur'an and their translations. As a translator, translation trainer and translation studies researcher, Davoudi Sharifabad has published some papers on the linguistic issues of translation.

Tengku Sepora Tengku Mahadi is an Associate Professor in Translation. She got her PhD from the University of Surrey. U.K. She is the Deputy Dean of Academic and Student Development in the School of Languages, Literacies, and Translation, Universiti Sains Malaysia. As an Associate Professor in Translation and Translation Studies Researcher, she has published papers and supervised $\mathrm{PhD}$ and Master students' theses. Her field of specialization is Theory and Practice of Translation, Pragmatic Texts, Text Analysis, Legal Translation, Interpretation, English For Specific Purposes.

Mohammad Sadegh Kenevisi is a PhD candidate of Translation Studies in the School of Humanities, Universiti Sains Malaysia. He has been an instructor of translation studies in Iran. His area of specialization is Translation Studies, Discourse Analysis, Literary Translation and Lexicography. 